\title{
Studying the corporate social responsibility in apparel and textile industry
}

\author{
DOI: $10.35530 / I T .070 .04 .1572$
}

DRAGOLJUB B. ĐORĐEVIĆ

MILOVAN VUKOVIĆ

SNEŽANA UROŠEVIĆ

NADA ŠTRBAC

ALEKSANDRA VUKOVIĆ

\section{REZUMAT - ABSTRACT}

Studiul responsabilității sociale a întreprinderilor în industria textilă și de îmbrăcăminte

În industria textilă și de îmbrăcăminte din țările în curs de dezvoltare, există o confuzie asupra definirii responsabilității sociale a întreprinderilor (RSI) și, în consecință, acest concept vag se reflectă în cercetarea fenomenului și a practicilor RSI. Întreprinderile mici și mijlocii și companiile mari doresc să încorporeze conceptul de responsabilitate socială a întreprinderilor (RSI) în cadrul strategiilor, politicilor și practicilor lor de afaceri, în special în era globalizării și a comerțului internațional. Acest studiu își propune să realizeze o introducere în domeniul responsabilității sociale a întreprinderilor (RSI), aplicat în industria textilă și de îmbrăcăminte. Prima parte a acestui studiu prezintă un rezumat al diferitelor definiții, teorii despre RSI și metode care au fost publicate de către specialiștii în domeniul RSI, atât în revistele din mediul academic, cât și în cele ale practicienilor. Întrucât campaniile mari integrează principiile RSI în politicile și practicile lor de afaceri, angajații trebuie să aplice valorile corporatiste adoptate. În partea a doua a acestui studiu, autorii au analizat diferitele cadre RSI aplicabile în practica din industria textilă și de îmbrăcăminte. Analiza a arătat că domeniul $R S I$ este în continuă dezvoltare, iar autorii oferă un set de recomandări cu privire la modul în care domeniul RSI poate fi aplicat în continuare în industria textilă și de îmbrăcăminte. În cele din urmă, ultima parte a acestui studiu subliniază unele aspecte metodologice care derivă din perspectivele teoretice adoptate în materie de RSI. De asemenea, se prezintă o analiză comparativă a diferitelor abordări de cercetare (cantitativă/calitativă, inductivă/deductivă, exploratorie/descriptivă /explicativă).

Cuvinte-cheie: responsabilitate socială a întreprinderilor (RSI), perspective teoretice, industria textilă/de îmbrăcăminte, abordări de cercetare

\section{Studying the corporate social responsibility in apparel and textile industry}

In the apparel and textile industry in developing countries, there is a confusion over the definition of CSR, and, consequently, this conceptual vagueness reflects itself on the research of the phenomenon and the practices of CSR. Small and medium enterprises and large companies are eager to incorporate the concept of corporate social responsibility (CSR) within their business strategies, policies and practices, especially in the era of globalization and international trade. This literature review articles aims to bring a better introduction to the field of corporate social responsibility (CSR) as studied by apparel/textile industry scholars. The first part of this review summarizes the different definitions, theories about CSR, and methods that have been used by management scholars working in the CSR field in both academic and practitioner management journals. As large corporations integrate the principles of CSR into their business policies and practices, company employees are expected to follow actions regarding the adopted corporate values. The authors in the second part of this review discuss different CSR frameworks applicable to the apparel/textile industry practice. The analysis shows that the CSR field is still evolving and the authors provide a set of recommendations on how to advance the CSR field to be applicable to the apparel/textile industry. Finally, the last part of this review highlights some methodological issues, originating from the adopted theoretical perspectives on CSR. A comparative review of different research approaches (quantitative/qualitative, inductive/deductive, explorative/ descriptive/explanatory) is also given.

Keywords: corporate social responsibility (CSR), theoretical perspectives, apparel/textile industry, research approaches

\section{INTRODUCTION}

"Social responsibility" is a term with a long history of use in the area of business management. According to Carroll, Howard Bowen was the first author who used this term, and, he stated in 1953 that social responsibility related to "the obligations of businessmen to pursue their policies, to make those decisions, or to follow those lines of action, which are desirable in terms of the objectives and values of our society" [1]. The extension of the concept to "corporate social responsibility" was attributed to the corporation's emerging prominence and leadership [1].

Corporate social responsibility, regardless of specific labelling, mainly means that business, apart from wealth creation, also has responsibilities for social issues created by business or by other causes [2]. Numerous abstract definitions have also been published in textbooks and papers, and, consequently, a number of scholars called for conducting research that will be focused rather on the practical level of 
CSR than the conceptual level. This paper supports this call and describes the current situation concerning CSR in practice of apparel/textile sector. Yet, there is a lack of this knowledge in regard to CSR development when the apparel/textile industry is at stake. As a relatively new term in the apparel and textile industry, Dickson and Eckman claim that it is important to clarify how CSR is used in this filed [3]. In fact, conceptualization of CSR in apparel and textile industry is a fundamental step in developing a theoretical base for this field [4].

This study first offers a short overview of corporate social responsibility (CSR) theories. The second part of this study attempts to clarify the concept of CSR as it relates to the vast array of apparel/textile business activities discussed by numerous authors. The last part of this paper pays attention to the methodological issues related to the CSR research in apparel/textile industry.

\section{THEORIES OF CORPORATE SOCIAL RESPONSIBILITY}

Various issues of CSR have been discussed for many years and these ideas have historical roots in Europe and worldwide [5]. From the theoretical standpoint, it is possible to discuss about various theories of CSR; and, all of them could be classified into four groups: (1) instrumental/wealth, (2) political/ social, (3) integrative, and (4) ethical theories. Within each theoretical branch there is a variety of approaches [6]. In this paper, more attention will be paid to the last (ethical) theoretical orientation.

Among integrative theories, created in order to integrate various social expectations from corporations, the "stakeholder management" and "corporate social performance" stand out. According to the "stakeholder view" of the firm, the term "stakeholder" can be defined as any group or individual who can affect or is affected by the achievement of the firm's objectives. These include entities such as: shareholders, employees, customers, suppliers, investors and society. Moreover, Freeman considered that this framework could be extended to other actors (external groups) such as: governments, competitors, consumer advocates, environmentalists, special interest groups (SIG) and media [7]. According to "corporate social performance" (CSP), business, beyond its economic and legal constraints, also has responsibilities for social issues caused by various activities.

Ethical theories offer various approaches such as: (1) normative stakeholder theory, (2) universal rights, (3) sustainable development, and (4) common good [3]. According to Matten and Crane, the stakeholder perspective is "a necessary process in the operationalization of corporate social responsibility" $[8, p$. 111]. Normative stakeholder theory (NST)-the core of normative perspective-represents a tool for making an ethical decision, and assumes that a corporation has a greater responsibility than just maximizing its profits. According to this theory, any socially responsible company is obligated simultaneously to pay attention to the "legitimate interests of all appropriate stakeholders", and, hence, has to "balance such a multiplicity of interests and not only the interests of the firm's stockholders" [6, p. 60]. Neither of these approaches relates to an entire range of issues included in CSR and, therefore, their combination seems to be an appropriate solution.

Starting from the 1990s, business systems are no more seen only as productive-economic entities (closed systems). Leadership of any apparel/textile company has put effort to improve, support and expand its activities, both in serving the domestic market and, mostly, with the aim to export and be competitive at the global market. In line with this, the concept of CSR is seen as a tool to increase economic performance. Also, many companies in the apparel/textile industry, having the possibilities of minimizing the costs of production, have started to outsource production facilities to Asia (mainly China and India), Africa, and, even South-East Europe. Therefore, the CSR concept appears as a consequence of the growing interdependence among numerous social groups (stakeholders), on the one hand, and the increased participation of society in business activities, on the other. Yet, CSR is a very heterogeneous theoretical discourse. It includes a variety of terms-occasionally used interchangeably during the 1980s and 1990s - to discuss corporate social responsibility: "corporate sustainability", "corporate citizenship", "corporate responsibility", "corporate governance", "corporate accountability", "ethical business", "sustainable entrepreneurship", "sustainability", etc. These alternative overlapping views are consistent with the earlier definitions of social responsibility, especially with that suggested by Carroll - the social responsibilities of business "encompass the economic, legal, ethical, and discretionary expectations that society has of organizations at a given point in time" [9, p. 500].

The European Commission offers a slightly better description of this concept. It defines CSR as "a concept whereby companies integrate social and environmental concerns in their business operations and in their interaction with their stakeholders on a voluntary basis" [10]. In other words, CSR is a company's commitment to conduct its activities in an economically, socially and environmentally sustainable manner whilst balancing the interests of diverse stakeholders. Similarly, the World Business Council for Sustainable Development (WBCSD) defined CSR as "the commitment by business to behave ethically and contribute to economic development while improving the quality of life of the workforce as well as of the local community and society at large" [11-12].

Although Carroll's model of the four responsibilities has been widely used over the years, it has some drawbacks. First of all, Carroll's original categorization did not fully capture the overlapping nature of the four categories - economic, legal, ethical and philanthropic - and, furthermore, "philanthropic responsibility should be placed in all categories because philanthropic activities are voluntary and therefore should 
not be considered responsibilities per se" [13, p. 43]. Therefore, it is not surprising that Carroll and Schwartz revisited (2003) the original model of CSR, aiming to overcome its limitations, offering an alternative model - the "Three-Domain Model of CSR" [14, p. 509].

This new model of CSR outlined three main responsibilities (economic, legal and ethical), while the former fourth category (philanthropic responsibility), was placed in both the economic and ethical domains. According to Carroll and Schwartz, the three domains overlap, as depicted in their Venn diagram, and, consequently, it is possible to identify seven possible types of CSR responsibility: purely economic, purely legal, purely ethical, economic/ethical, economic/legal, legal/ethical, and, finally, economic/ legal/ethical. Regarding the limitations of the "Three Domain Model of CSR", the authors point out that economic, legal and ethical responsibilities are "inseparable and interwoven", and, consequently, any action cannot really be recognized as either purely legal, purely ethical or purely economic [14, p. 520]. The relative importance that one assigns to each of the three CSR dimensions proposed by Carroll and Schwartz is not fixed. It may be, what is common in an empirical study, a reflection of respondents' social responsibility preference (attitude). Michailides and Lipsett called this the "corporate social responsibility orientation” (CSRO) [15, p. 300].

Although numerous definitions of CSR tend to be applicable to all types of organizations, they cannot fulfil this task. Dahlsrud, ten years ago, analyzed no fewer than 37 definitions (1980-2003), and noticed that, for the most part, these definitions are congruent [16]. Various definitions of CSR rather tend to describe this phenomenon than to offer an explicit definition of what corporate social responsibility should be. Dahlsrud also identified five dimensions that are most frequently tied to the CSR concept: stakeholder, social, economic, voluntariness and environmental. This apparent connection implies that any CSR initiative has to consider the economic and social interests of relevant stakeholders in a voluntary way [17]. Some scholars suggest an extension of the CSR concept in order to incorporate the international aspect of business activities, and, call for socalled "global responsibility" [1]. It has been known for a long time that contemporary business extends national borders (primarily due to the globalization process) and that fact has already been taken into account in many similar concepts such as that of "business ethics". Otherwise, the term "social", as Dickson and Eckman rightly noticed, was never limited geographically, and, hence, the notion of "global responsibility" in the context of corporate business offered "nothing beyond what earlier authors had defined as social responsibility" [17, p. 181].

The vagueness of numerous CSR definitions impedes their corporate implementation, and, as Van Marrewijk observed, does not allow academic debate [13]. When we talk about the apparel and textile industry, social responsibility and CSR are not only new concepts, as mentioned earlier, but also still relatively new terms [3].

\section{CORPORATE SOCIAL RESPONSIBILITY IN APPAREL AND TEXTILE INDUSTRY}

Starting in the 1970s, the apparel/textile industry began to reorganize continuously thanks to the intensification of the globalization process that implies the removal of trade barriers and the acceleration of the flow of goods, services, capital and labor [18-20]. The apparel/textile industry capacities of large global corporations have been increasingly outsourced from once traditional industrial regions of the developed world. Bearing in mind that apparel and textile production is a highly labor-intensive activity, the leading corporations in this field, searching for cheap labor, outsource their production processes into highly populated regions (above all, China and India), which are characterized by a surplus of labor and a deficit of work, and, consequently, significantly lower income. This has mainly contributed to the apparel/textile industry, more so than other branches, acquiring an extremely global character [21]. Despite this, the apparel/textile industry witnesses highly expressed regional differences that relate to state regulations, employment conditions, environmental protection, and amount of income. This heterogeneity forces the large textile corporations to create different business conditions in certain parts of the world, which does not necessarily have to be in line with the common ethical norms.

The European apparel/textile companies are faced with more stringent regulations in the area of environmental protection and higher labor costs [22]. Therefore, the apparel/textile sector in Europe increasingly instigates innovation activities both in the processes and in the high-quality products. On the other hand, displacing the apparel/textile industry capacities to less developed parts of the world has brought about a series of positive changes on the social plane. The development of the apparel/textile industry has contributed to the economic renewal of the developing countries by enabling the opening of a great number of workplaces that do not require specialized knowledge and skills. A large number of people from marginalized social groups (particularly women) would find it hard to secure employment without investing in the apparel/textile industry in the rural areas of these countries. This is particularly important bearing in mind the fact that from approximately 26.5 million of employees in the apparel/textile sector worldwide, $70 \%$ are women. Also worth mentioning is that language barriers do not represent a serious obstacle for getting involved in the production processes of the apparel/textile industry, which facilitates the path toward workplaces for migrant labor. All of this leads to the developing countries achieving three quarters of the global apparel export, i.e. around $50 \%$ of the textile export [23-24].

The growing international character of the apparel/ textile industry in recent decades, described above, 
is followed by an increased interest in various issues of different stakeholders in this industry. Consequently, the models of CSR applicable to the apparel/textile industry have become the subject of numerous studies. The study conducted by Dickson and Eckman is one of the influential studies in the area of CSR in the apparel industry [3]. The authors used survey research methods to determine apparel and textile scholars' definition of the term "socially responsible apparel/textile business". Active members of the International Apparel and Textile Association (ITAA) participated in this survey. Of 523 ITAA members included in the sample, 87 completed the survey for a response rate of $16.6 \%$. It is important to note that all the respondents were ITAA members associated with academic institutions, and almost two thirds of them were employed in academic positions. A wide scope of social responsibilities topics in this survey was recognized as important for apparel and textile teaching staff. To the vast majority of respondents $(87 \%)$, the working conditions were important, and almost $80 \%$ considered child labor, consumerism and environmental degradation as important to point out. Based on the obtained responses from the conducted survey, Dickson and Eckman found out a definition of a socially responsible apparel/textile business as follows:

- An orientation encompassing the environment, its people, the apparel/textile products made and consumed, and the systematic impact that production, marketing, and consumption of these products and their component parts has on multiple stakeholders and the environment.

- A philosophy that balances ethics/morality with profitability, which is achieved through accountability-based business decisions and strategies.

- A desire for outcomes that positively affect, or do very little harm to, the world and its people $[3, p$. 188].

The Global Reporting Initiative (GRI) is the most frequently used framework for providing guidance on CSR performance disclosure. The GRI has also developed specific sector supplements, including a pilot version specifically for the apparel and footwear industry - Apparel and Footwear Sector Supplement (AFSS). The AFSS provides a definition of CSR reporting as a "practice of measuring, disclosing and being accountable for organizational performance while working towards the goal of sustainable development provides a balanced and reasonable representation of the sustainability performance of the reporting organization positive and negative contributions" [26, p. 55]. Since this concept of CSR encompasses a wide range of issues such as "human rights", "labor", "social", "environmental", "product responsibility" and "economic issues", it is difficult to achieve that all dimensions be comprehensively examined in one study [25]. This classification is similar to that suggested by Kunnari et al.; social impacts are also divided in six categories: "environment", "economics", "employment", "housing and community", "local livelihoods" and "health" [27].
The ISO 26000 standard can also be used as a framework to address the CSR in apparel and textile industry. The ISO 26000 has divided CSR into seven core themes: "organizational governance", "human rights", "labor practices", "the environment", "fair operating practices", "consumer issues" and "community involvement and development". For every theme (subject), a number of associated issues are listed. For instance, the environment includes prevention of pollution, sustainable resource use, and protection of the natural environment. The ISO 26000 standard offers guidance on how organizations can operate in a social responsible way, contributing to the health and well-being of society. ISO 26000 standard states that the engagement with stakeholders is crucial to social responsibility (especially with those such as employees, customers, affected communities and the general public), and, also, outlines the CSR as companies' and other organizations' contribution to sustainable development [28].

\section{QUALITATIVE RESEARCH METHODS IN CSR APPAREL/TEXTILE INDUSTRY}

There is a number of research approaches to study corporate social responsibility in the apparel and textile industry, especially in terms of its practice. First of all, the researchers themselves create a general direction of a particular study. A researcher's preunderstanding and adopted theoretical perspective and personal experiences, for instance, direct the research in many cases. Gummesson considers that a pre-understanding may be beneficial in order to understand the business culture in which the company operates. Among some drawbacks, the problem of reduced openness to new information and innovation might be mentioned [29]. In terms of apparel/textile context, the focus of this research could be on understanding perceptions of CSR among manufacturers in developing countries; mostly in India, China, etc. Because little research exists which examines manufacturer perceptions in apparel/textile, a better understanding is needed. Unlike developing countries, some other issues of CSR in apparel/textile industry have been examined in developed world such as, for instance, companies' motivation factors to adopt CSR practice, relationship between CSR and economic performance and green fashion and sustainability. Therefore, various issues on CSR might be somewhat sensitive in apparel/textile industry such those relating to factory working conditions and the treatment of workers often arise. Also, if the study is emic in nature and aims to capture the insider's perspective, then qualitative methodologies are typically the most appropriate. For example, Gupta has successfully used a qualitative research design (in particular, ethnography) in his study of CSR in apparel/ textile industry in India [14].

Although research within the area of CSR has increased over time, it seems that the research at the practical level is limited. In apparel and textile industry, exploratory research may lead to useful knowledge. 
As an excellent example of qualitatively, exploratory research is a recently conducted study of the Romanian business retail with garment products within the context of globalization and sustainable development [30]. The method used for conducting this research was the survey, the technique employed was the in-depth interview and the instrument was the discussion guide. The research confirms one of given assumptions that the existing ethical principles, if implemented within the business retail with garment products, will guarantee a balanced development, in compliance with environmental protection regulations.

Despite widely used quantitative methodologies in studies related to CSR, the advantages of qualitative methods should not be underestimated. Namely, qualitative research attempts to understand the real world for an individual or a group of individuals and how they see themselves and their relations to the "environment, people/society, systems, institutions, business, selections of business partners, profits, and animal rights", let us name these entities according to the framework suggested by Dickson and Eckman [3, p. 186]. In other words, qualitative research focuses on words, narratives, observations, visual portrayals, meanings of used symbols, interpretations and other expressive descriptions [29]. The advantages of the case method have been confirmed in recently conducted research on CSR in apparel/ textile companies, resulting in numerous papers published during the last two decades. Case study research methods are applicable to study of various aspects of CSR in apparel/textile industry. The vast majority of these issues requires a rich understanding of the context as well as an extensive and in-depth description of a given phenomenon. The categories of CSR, considered in this paper, reflect the impacts of apparel/textile industry on a general scale, but in any research of this type they are used as guidelines, through which the social aspects are conceptualized. The actual scrutiny of the social dimensions is carried out on the basis of themes, and associated issues, found out from empirical data. And, doing so, the characteristics of the selected case are emphasized.

\section{CONCLUSION}

In recent decades, the apparel/textile industry has been facing numerous demands from various interest groups. One of the crucial factors for the long-lasting success of major apparel/textile companies is the ability to reconcile their interests with the interests of communities in which they operate. Consequently, this type of industry and its management, along with other industries relating to numerous stakeholders, needs to adopt a more comprehensive approach in order to address these demands. Since the relationship between local communities and apparel/textile companies is the most important from the social standpoint, the vast majority of studies (mentioned in the review) relied on the integrative theoretical perspectives (stakeholder management) and particular methodology - the case method.

Corporative social responsibility is becoming a concept whose different aspects are increasingly investigated in the apparel/textile industry. Among the topics that mainly stem from the ISO 26000 standard, the most commonly examined are those that are related to human rights and working conditions, particularly in the apparel/textile sector of the developing countries. The environmental protection issues also represent a significant area in CSR analysis.

On the basis of the analysis of the CSR concept from the standpoint of the apparel/textile sector it can be concluded that responsibility moves between two opposed orientations-economic responsibility, on the one hand, and ethical and philanthropic responsibility, on the other. Numerous issues encountered by the apparel/textile sector create the need for combining various ethical orientations. Large corporations within this branch of economy, as well as small and medium enterprises, gain profit by offering their customers high-quality products, thus improving their own reputation.

\section{ACKNOWLEDGEMENT}

Prepared as a part of the project Sustainability of the Identity of Serbs and National Minorities in the Border Municipalities of Eastern and Southeastern Serbia (179013), conducted at the University of Niš - Faculty of Mechanical Engineering, and supported by the Ministry of Science and Technological Development of the Republic of Serbia.

\section{BIBLIOGRAPHY}

[1] Carroll, A., Corporate social responsibility, In: Business \& Society, 1999, 38, 3, pp. 268-295

[2] Carroll, A., The pyramid of corporate social responsibility: toward the moral management of organizational stakeholders, In: Business Horizons, 1991, 34, pp. 39-48

[3] Dickson, M.A., Eckman, M., Social responsibility: the concept as defined by apparel and textile scholars, In: Clothing \& Textiles Research Journal, 2006, 24, 3, pp. 178-191

[4] Winakor, G., Research in fashion merchandising - the need for a theoretical base, In: Clothing \& Textiles Research Journal, 1988, 7, 1, pp. 31-35

[5] Carroll, A., The Oxford handbook of corporate social responsibility, Oxford University Press, Oxford, 2008

[6] Garriga, E., Melé, D., Corporate social responsibility: mapping the territory, In: Journal of Business Ethics, 2004, 53, pp. $51-71$

[7] Freeman, E., Strategic management: a stakeholder approach, Pitman, Boston, 1984 
[8] Matten, D., Crane, A., Corporate citizenship: Toward an extended theoretical conceptualization, In: The Academy of Management Review, 2005, 30, 1, pp. 166-179

[9] Carroll, A.B., A three-dimensional conceptual model of corporate performance, In: Academy of Management Review, 1979, 4, pp. 497-505

[10] European Commission (2001), Commission Green Paper 2001: Promoting a European framework for corporate social responsibility, COM (2001)366 Final

[11] World Business Council for Sustainable Development, Corporate social responsibility: Meeting changing expectations, Geneva, Switzerland: World Business Council for Sustainable Development, 1999

[12] Bouten, L., Everaert, P., Liedekerke, L. V., Moor, L. D., Christiaens, J., Corporate social responsibility reporting: $A$ comprehensive picture? In: Accounting Forum, 2011, 35, pp. 187-204

[13] Schwartz, M.S., Carroll, A.B., Corporate social responsibility: a three-domain approach, In: Business Ethics Quarterly, 2003, 13, 4, pp. 503-530

[14] Gupta, M., Corporate social responsibility in the global apparel industry: an exploration of Indian manufacturers' perceptions (dissertation), University of north Carolina: Greensboro, 2012

[15] Michailides, T.P., Lipsett, M.G., Surveying employee attitudes on corporate social responsibility at the frontline level of an energy transportation company, In: Corp. Soc. Responsib. Environ. Mgmt., 2013, 20, pp. 296-320

[16] Dahlsrud, A., How corporate social responsibility is defined: an analysis of 37 definitions, In: Corp. Soc. Responsib. Environ. Manag., 2008, 15, pp. 168-182

[17] Van Marrewijk, M., Concepts and definitions of CSR and corporate sustainability: Between agency and communion, In: Journal of Business Ethics, 2002, 45, 2/3, pp. 95-105

[18] Dicken, P., Global shift: Mapping the changing contours of the world economy, $6^{\text {th }}$ ed., London: Sage publications, 2011

[19] Dabija, D.C., Pop, N., Postelnicu, C., Ethics of the garment retail within the context of globalization and sustinable development, In: Industria Textila, 2017, 67, 4, pp. 270-279

[20] Tudor, L., Changes in textile and clothing industry, In: Industria Textila, 2018, 69, 1, pp. 37-42

[21] Perry, P., Towers, N. (2013), Conceptual framework development for CSR implementation in fashion supply chains, In: International Journal of Physical Distribution \& Logistics Management, 2013, 43, 5-6, pp. 478-500

[22] Eurostat, European business: facts and figures, 2009

[23] UNDP EC, Turkey corporate social responsibility: baseline report, 2008

[24] Vuković, M., Urošević, S. Vuković, A., Korporativna društvena odgovornost u tekstilnoj industriji In: Tekstilna Industrija, 2017, 65, 2, pp. 4-11

[25] Woo, H., Jin, B., Culture doesn't matter? The impact of apparel companies' corporates social responsibility practices on brend equity, In: Clothing and Textile Research Journal, 2016, 34, 1, pp. 20-36

[26] GRI, Sustainability reporting guidelines \& apparel and footwear sector supplement, Amsterdam, the Netherlands; Electronic Pilot Version: GRI, 2011

[27] Kunnari, M, Niemelä, M., Suikkanen, A, Kaivoshankkeiden käynnistämisvaiheiden ennakoidut sosiaaliset vaikutukset ja vaikutusten hallinnan tutkimusohjelma, Lapin yliopiston yhteiskuntatieteellisiä julkaisuja B. Lapin yliopiston yhteiskuntatieteiden tiedekunta, Rovaniemi, 2008

[28] ISO, Guidance on social responsibility, ISO 26000: 2010, IDT, 2010

[29] Gummesson, E., Qualitative methods in management research, Sage Publications Inc., Thousand Oaks, 2000

[30] Miron, A., Ciobanu, L., Matoschi, O., Furdui, L.M., Pruteanu, M.E., The restructuring of peasant households under the impact of urbanization by intensifying the knowledge transfer process and the collaboration with the textile industry, In: Industria Textila, 2014, 65, 3, pp. 173-178

Authors:

DRAGOLJUB B. ĐORĐEVIĆ ${ }^{1}$, MILOVAN VUKOVIĆ², SNEŽANA UROŠEVIĆ², NADA ŠTRBAC ${ }^{2}$, ALEKSANDRA VUKOVIĆ $^{3}$

${ }^{1}$ Faculty of Mechanical Engineering, University of Niš, Aleksandra Medvedeva 14, Niš, Serbia, e-mail: brkab@junis.ni.ac.rs

${ }^{2}$ Technical Faculty in Bor, University of Belgrade, Vojske Jugoslavije 12, Bor, Serbia, e-mail: mvukovic@tfbor.bg.ac.rs

${ }^{3}$ High Railway School of Professional Studies, Zdravka Čelara 14, Beograd, Serbia

Corresponding author:

SNEŽANA UROŠEVIĆ

e-mail: surosevic@tfbor.bg.ac.rs, snezanaur@gmail.com 